Brit. J. vener. Dis. (1957), 33, 180.

\title{
NOVOBIOCIN, SPIRAMYCIN, AND AMINITROZOLE IN THE TREATMENT OF NON-GONOCOCCAL URETHRITIS*†
}

\author{
BY \\ R. R. WILLCOX \\ St. Mary's Hospital, London
}

During recent months, trials have been undertaken with three relatively new substances in the treatment of non-gonococcal urethritis in males.

Two of these, novobiocin and spiramycin, are antibiotics. Novobiocin (also known as Streptonivicin, Albamycin, Cathomycin, Cathocin) has been prepared from the Streptomyces niveus and from Streptomyces spheroides and was developed in the United States. Also, it has been shown that Cardelmycin is the same substance. Spiramycin (Rovamycin), on the other hand, was developed in France and is prepared from the Streptomyces ambofaciens.

The third substance, Aminitrozole (2-acetylamino-5-nitrothiazole), has been used successfully for some years to prevent enterohepatitis (blackhead disease) of turkeys. This condition is due to a flagellated protozoon, and in the USA some success has been claimed for the drug in human trichomoniasis. (This has not been substantiated by the writer who has had 100 per cent. of failures in sixteen female cases treated.)

87 previously untreated cases of non-gonococcal urethritis have been treated with spiramycin, forty with Novobiocin, and 49 with aminitrozole. The results are shown in Tables I to III.

TABLE I

TREATMENT OF NON-GONOCOCCAL URETHRITIS WITH SPIRAMYCIN

\begin{tabular}{c|c|c|c|c}
\hline \multicolumn{1}{c|}{$\begin{array}{c}\text { Duration of } \\
\text { Follow-Up }\end{array}$} & $\begin{array}{c}\text { No. } \\
\text { Followed }\end{array}$ & Failures & $\begin{array}{c}\text { Cumulative } \\
\text { Failure-Rate } \\
\text { Per cent. }\end{array}$ \\
\hline \multirow{4}{*}{ Days } & 0 & 87 & - & - \\
& $1-3$ & 77 & 1 & $1 \cdot 3$ \\
& $4-7$ & 75 & 1 & $2 \cdot 6$ \\
& $8-14$ & 65 & 4 & $8 \cdot 9$ \\
Months & $15-21$ & 58 & 2 & $12 \cdot 3$ \\
& $22-28$ & 51 & 1 & $14 \cdot 3$ \\
\hline & $1-2$ & 45 & 5 & $25 \cdot 4$ \\
\hline
\end{tabular}

* Received for publication May 6, 1957.

+ Paper presented at the XI International Congress on Dermatology, Stockholm, July-August, 1957.
TABLE II

TREATMENT OF NON-GONOCOCCAL URETHRITIS WITH NOVOBIOCIN

\begin{tabular}{c|c|c|c|c}
\hline \multicolumn{1}{c|}{$\begin{array}{c}\text { Duration of } \\
\text { Follow-Up }\end{array}$} & $\begin{array}{c}\text { No. } \\
\text { Followed }\end{array}$ & Failures & $\begin{array}{c}\text { Cumulative } \\
\text { Failure Rate } \\
\text { Per cent. }\end{array}$ \\
\hline \multirow{5}{*}{ Days } & 0 & 40 & - & - \\
& $1-3$ & 36 & $\overline{7}$ & $19 \cdot 4$ \\
& $4-7$ & 36 & 6 & $40 \cdot 8$ \\
$8-14$ & 28 & 4 & $59 \cdot 8$ \\
$15-21$ & 21 & 1 & $66 \cdot 5$ \\
\hline \multirow{2}{*}{ Months } & $22-28$ & 15 & 2 & $80 \cdot 8$ \\
& $1-2$ & 14 & - & - \\
\hline
\end{tabular}

TABLE III

TREATMENT OF NON-GONOCOCCAL URETHRITIS WITH AMINITROZOLE

\begin{tabular}{c|c|c|c|c}
\hline \multicolumn{2}{c|}{$\begin{array}{c}\text { Duration of } \\
\text { Follow-Up }\end{array}$} & $\begin{array}{c}\text { No. } \\
\text { Followed }\end{array}$ & Failures & $\begin{array}{c}\text { Cumulative } \\
\text { Failure Rate } \\
\text { Per cent. }\end{array}$ \\
\hline \multirow{4}{*}{ Days } & 0 & 49 & - & - \\
& $1-3$ & 45 & 1 & $2 \cdot 2$ \\
& $4-7$ & 43 & 11 & $28 \cdot 0$ \\
& $8-14$ & 29 & 6 & $48 \cdot 7$ \\
\multirow{3}{*}{ Months } & $15-21$ & 19 & 1 & $54 \cdot 0$ \\
& $22-28$ & 18 & 1 & $59 \cdot 6$ \\
\hline & $1-2$ & 15 & 2 & $72 \cdot 9$ \\
& $2-3$ & 3 & - & - \\
\hline
\end{tabular}

No attempt has been made to differentiate relapse from re-infection. Of 87 patients treated with spiramycin, 77 were followed and there were sixteen failures (20.8 per cent.) within 2 to 3 months of observation. Of forty patients treated with Novobiocin, 36 were followed and there were twenty failures (55.6 per cent.). Of 49 treated with aminitrozole, 45 were followed and there were 22 failures ( 48.9 per cent.).

In Table IV (opposite), these results are compared with those in other previously untreated cases, treated by different means under similar conditions and criteria of study. 
TABLE IV

RESULTS OF TREATMENT BY DIFFERENT MEANS OF 899 PREVIOUSLY UNTREATED CASES OF NON-GONOCOCCAL URETHRITIS

\begin{tabular}{l|c|c|c|c|c}
\hline \multicolumn{1}{c|}{ Drug } & $\begin{array}{c}\text { Usual } \\
\text { Dose } \\
(\mathrm{g} .)\end{array}$ & Treated & $\begin{array}{c}\text { Fol- } \\
\text { lowed }\end{array}$ & Failures & $\begin{array}{c}\text { Per cent. } \\
\text { Failure of } \\
\text { Those } \\
\text { Followed }\end{array}$ \\
\hline Sigmamycin .. & 6 & 43 & 34 & 5 & $15 \cdot 2$ \\
Oxytetracycline & $5-6$ & 85 & 82 & 13 & $15 \cdot 9$ \\
Tetracycline .. & 6 & 124 & 108 & 20 & $18 \cdot 5$ \\
Chlortetra- \\
cycline & $5-6$ & 115 & 108 & 20 & $18 \cdot 5$ \\
Spiramycin .. & $10-20$ & 87 & 77 & 16 & $20 \cdot 8$ \\
Erythromycin.. & 6 & 101 & 85 & 23 & $27 \cdot 1$ \\
Streptomycin* & $2-4$ & 62 & 58 & 22 & $37 \cdot 9$ \\
Sulphonamides & $20-28$ & 55 & 53 & 21 & $39 \cdot 6$ \\
Penicillin* & $1-3 \cdot 6$ & 70 & 65 & 26 & $40 \cdot 0$ \\
(mega & & & & \\
Chloram- & units) & & & & \\
phenicol & $5-6$ & 39 & 37 & 15 & $40 \cdot 5$ \\
Aminitrozole ... & $1 \cdot 8-2 \cdot 1$ & 49 & 45 & 22 & $48 \cdot 9$ \\
Novobiocin .. & $6-12$ & 40 & 36 & 20 & $55 \cdot 6$ \\
Placebo & $\ldots$ & 29 & 22 & 15 & $68 \cdot 2$ \\
\hline Totals .. & $\ldots$ & 899 & 810 & 238 & $29 \cdot 3$ \\
\hline
\end{tabular}

${ }^{*}$ Given by injection.

\section{Summary}

(1) The tetracycline antibiotics, oxytetracycline, chlortetracycline, and tetracycline, alone or in combination with oleandomycin, give the best results in the treatment of non-gonococcal urethritis. Comparable results are obtained with spiramycin. Good results are also obtained with erythromycin.

(2) By comparison, indifferent results are obtained with streptomycin, sulphonamides, penicillin, and chloramphenicol.

(3) Poor results, comparable with those in which only a placebo was given, were obtained with Novobiocin and aminitrozole.

Grateful acknowledgements are expressed to the Upjohn Company of Kalamazoo, Michigan, U.S.A., for kindly providing the Novobiocin (Streptonivicin), and to Messrs. May and Baker Ltd. of Dagenham, Essex, for providing the spiramycin (Rovamycin). The aminitrozole used was Tritheon manufactured by Ortho Pharmaceutical Ltd. of High Wycombe, Bucks. 